\title{
The Typewritten Market: Shari'ah-Compliance and Securitisation in the Law of Islamic Finance
}

Author

Affiliation

E-mail

\begin{abstract}
Taking inspiration from Szymborska's poem 'The people on the bridge' (1986) and Messick's Calligraphic State (1993), this article interprets the law of Islamic finance as evidence of a radical shift in the social anthropology of Islamic law from classical to contemporary times. To this aim it highlights the changes from figh in medieval trade (where individual actions were judged by rules legitimised by their local context) to the current process of Shari'ah-compliance, arguing that this process belongs to a textual polity where standardised certificates, contracts and securities have replaced actual social relations in the global financial market. In the light of this, the article advances the notion of Typewritten Market to depict the nature of Islamic finance as a socio-economic space embodying a 'de-materialised Šaríah': that is to say, a meaning of Islamic law whose contemporary time belongs more to legal/financial technology rather than to Muslim human action.
\end{abstract}

Keywords

Islamic finance - Shari'ah-compliance - Islamic law - anthropology

1

Introduction. Between the Space of Islamic Finance and the Time of Islamic Law: How Texts are Vehicle of Meaning

Dealing with the law of Islamic finance, a valuable starting point can be found in the Encyclopedia of Islam.

Islamic finance denotes financial transactions in compliance with Islamic principles. It is a business practice guided by Islamic law that has evolved in the context of global financial markets and is the most important application of Islamic contract law today. Moreover, it is the key area where the propositions of Islamic economics... are put into practice. ${ }^{1}$

The contributor, Kilian Bälz, refers to Islamic law in various ways ('compliance with Islamic principles'; 'application of Islamic contract law'; 'the propositions of Islamic economics'). More precisely, after listing in the entry the general principles of Islamic banking (namely: (i) interest on loans is prohibited; (ii) speculation is unlawful; (iii) trading in debt is not allowed) and the contracts generally in use (i.e. murābaḥa, mušāraka, muḍāraba, ijāra, istișnā'), plus the issuance of șukūk (Islamic securities certificates of investments, commonly said 'Islamic bonds'), he soon specifies his definition in the sense of Shari'ah-compliance. ${ }^{2}$

Shari'a compliance - abiding by the prescriptions of Islamic law - is what sets Islamic finance apart from conventional finance. The review and certification process that creates the Islamic legitimacy for Islamic financial transactions and which constructs the normative framework

Acknowledgements: ...

' K. Bälz, 'Finance', in K. Fleet, G. Krämer, J. Nawas \& E. Rowson (eds.), Encyclopedia of Islam, Three, online at: https://referenceworks.brillonline.com/browse/encyclopaedia-of-islam-3, accessed 15 April 2019.

2 See also K. Bälz, 'Sharia risk? How Islamic finance has transformed Islamic contract law', in Occasional Publications n. 9, Islamic Legal Studies Program (Harvard: Harvard Law School, 20o8). 
in which Islamic banks operate is central to Islamic finance. Islamic financial transactions are normally reviewed and certified by a board of Islamic scholars (the so-called Shari'a board), which renders an opinion (termed fatwa, in reference to traditional Islamic law). ${ }^{3}$

While reading the Encyclopedia two elements have struck my attention.

First, what appears to be the most relevant connotation of Islamic finance law ('Shari'a compliance - abiding by the prescriptions of Islamic law - is what sets Islamic finance apart from conventional finance') clashes with a legal reality where, as Bälz admits, 'Islamic finance prospers... in jurisdictions where the law does not enforce the prescriptions of Islam relating to interest and speculation, and today those hubs include Dubai, Kuala Lumpur, and London'. ${ }^{4}$ Thus, Islamic financial institutions operate according to commercial dynamics where municipal systems apply or not Shari'ah; ${ }^{5}$ notwithstanding, the persistent reference to Islamic law (enforced or not) functions for them as a specific 'identity mark' (one could say 'market brand').

Second, as much these institutions identify themselves with Shari'ah-compliance (which 'creates the Islamic legitimacy' of financial transactions and șukūk), their claim to comply with Islamic law seems to be made as if no radical transformation would have affected the meaning of the concept along the centuries (Bälz suggests this historical variance when he notes that Islamic scholars' opinions are named fatwa 'in reference [in homage?] to traditional Islamic law'). But the normative space of Islamic finance cannot be properly understood, I believe, without locating 'Islamic law' in-time as a socioanthropological construction. In fact, if concepts go far beyond our singular existence by depicting a collective identity that recalls the past to guide the future, their imag(in)ing power of re-presentation is immersed in social reality and so subject to present (i.e. our presence in-time).

Poets' intuition has unveiled the power of imag(in)ing much better than jurists' acumen, whose wisdom is often more devoted to practical aims. Hence, in the poem 'The people on the bridge ${ }^{6}$ Nobel Prize Wisława Szymborska (1923-2012) comments on our 'odd planet', whose inhabitants, in her opinion, 'are odd, too'. In fact, they 'are subject to time, but they won't admit it': rather they 'have their own ways of expressing protest'. For instance, they make 'little pictures', like the one printed by Japanese master Utagawa Hiroshige (1797-1858) ('a rebel [...] who, by the way, died long ago and in due course', as Szymborska wittily remarks) under the title Sudden Shower over Shin-Ōhashi Bridge and Atake (1857).

At first glance, nothing special.

What you see is water.

And one of its banks.

And a little boat sailing strenuously upstream.

And a bridge over the water, and people on the bridge.

It appears that the people are picking up their pace

because of the rain just beginning to lash down

from a dark cloud.

3 Bälz, supra note 1.

4 Bälz, ibid.

5 On the matter, from different angles, see J. Ercanbrack, The Transformation of Islamic Law in Global Financial Markets (Cambridge: Cambridge University Press, 2015); N. H. D. Foster, 'Islamic finance law as an emergent legal system', Arab Law Quarterly 21(2) (2007): 170-188; J. Pollard \& M. Samers, 'Governing Islamic finance: territory, agency, and the making of cosmopolitan financial geography', Annals of the Association of American Geographers 103(3) (2013): 710-726.

6 W. Szymborska, 'The people on the bridge' (original Polish version, 1986), in W. Szymborska, View with a Grain of Sand. Selected Poems (transl. by S. Barańczak and C. Cavanagh; London: Faber and Faber, 1996) 167-169. 
The thing is, nothing else happens.

The cloud doesn't change its colour or its shape.

The rain doesn't increase or subside.

The boat sails on without moving.

The people on the bridge are running now

exactly where they ran before. ${ }^{7}$

With regard to the imag(in)ing power of concepts, this article concentrates on something less beautiful than Hiroshige's print, though probably more appealing to the small circles of comparative lawyers and legal anthropologists (another two kinds of 'odd people', Szymborska would have said): namely, the law of Islamic finance. Precisely, these pages are 'my own way of expressing protest' against the use of the phrase 'Islamic law' in Islamic finance as if the concept were not-subject-to-time and no variance of meaning would have affected its employ along the centuries.

At this point we can imagine being on the middle of Hiroshige's Bridge, running under the rain in the search for this meaning. But how to cross safely the Bridge? To this aim, I think, important clues can arise from the texts of Shari'ah-compliance certifications that 'creates the Islamic legitimacy' for Islamic transactions, contracts and securities (sukuk). ${ }^{8}$

Assuming texts as vehicles of meaning belongs to the core of a well-known work of legal anthropology, namely Brinkley Messick's Calligraphic State (1993). ${ }^{9}$ By investigating local papers produced in the town of Ibb (a provincial capital in Šăfi'î Lower Yemen) between 1974 and 1976, Messick studies handwritten documents as a vehicle of a wide spectrum of personal and political relationships. In particular, his research highlights the hegemonic role of legal texts makers in the 'interlocking of a polity, a social order, and a discursive formation,', which arises through the bilateral conjunction 'between the literary processes behind the constitution of authority in texts and the social and political processes involved in articulating the authority of texts.' ${ }^{11}$ Within this textual polity (where four fundamental moments, namely 'authority', 'transmission', 'interpretation' and 'inscription', are interconnected)

[d] ocuments are mediations, their writers mediators, between the enduring text of shari'a law and the particular events of the world. [It is in this frame that we can] ... consider the

$7 \quad$ Szymborska, ibid., p. 167 .

8 In this article I have opted for the simplified transliteration 'Shari'ah' when speaking of compliance (see $\S 3$ ), keeping the more precise 'Šarī'ah' when referring to fiqh (see $\S 2$ ). The reader may have also noted here the passage from the graphical form 'șukūk' to 'sukuk', that I will maintain in the rest of the text. I would like to explain this stylistic choice with two arguments. First, both the forms 'Shari'ah-compliance' and 'sukuk' (not in italics and with simplified transliteration) are commonly employed both in international finance and academic literature - so, in this sense, I just abide by current use. Second, I feel that both the graphical variants 'Shari'ah' and 'sukuk' have the advantage to stress how much standardisation has affected the development of Islamic finance making 'more Latin' and 'not italics' its alphabet (see note 29). In this direction 'Shari'ah'/'sukuk' reflect the shift in the social anthropology of Islamic law that is the ultimate argument of the article (see Conclusions).

9 B. Messick, The Calligraphic State: Textual Domination and History in a Muslim Society (Berkeley and Los Angeles: University of California Press, 1993).

1 Messick, ibid., p. 1.

${ }^{11}$ Ibidem. 
problematic way documents fit the law to the world, and the world to law - rendering form historical and giving form to history. ${ }^{12}$

Inscribed legal texts transmit authority within a shared practice of interpretation, where the process of 'entextualisation' rests on a double relationship.

The first is a movement from Text to text, that is, from law on the books to the document; while the second is from the world (as event) to text, from a specific human undertaking, such a sale, to the document. Behind a given document text is the law, in front of it is the world... $[\ldots]$ The writer, ... through his document text, mediates both the re-production of the Text and the incorporative 'translation' of the world. ${ }^{13}$

With reference to the process of entextualisation, this article investigates the extent to which the transmission of Šarīah value (inscribed in the concept of 'Islamic law') has actually changed from medieval trade to today's Islamic finance contracts and securities: and in this regard, it argues that the law of Islamic finance represents evidence of a radical shift in the social anthropology of Islamic law from classical to contemporary times.

To support this thesis the article focuses on the differences between figh legal texts - where actions were judged by rules legitimized by their own local context $(\S 2)$ - to the current process of Shari'ahcompliance - where certifications own a legitimacy that is formulated context-less -, and suggests that this process belongs to a textual polity where standardised certificates, contracts and securities have replaced actual social relations in the global financial market ( $\$ 3$ ). To conclude, the notion of Typewritten Market (clearly a homage to Messick) will be advanced to describe Islamic finance as a socio-economic space embodying a 'de-materialised Šarī'ah': that is to say, a meaning of Islamic law whose contemporary time belongs more to legal/financial technology rather than to Muslim human action. In this context Shari'ah-compliance will be also interpreted as a 'dialectical signature' for Muslim believers: their 'way of expressing protest' towards conventional finance that is simultaneously proof of the world of legal/financial technology to which (of which?) they are subject(s) (§ 4).

Fiqh Legal Texts in Medieval Trade: Locating Šarīah in Context

With regard to classical figh an important caveat comes from Norman Calder, who notes how

Western scholarship (even when written by Muslims) has rarely presented Islamic law in such a way as to demonstrate its values rather than the values of the observer. It is legal practice in the Western sense... that dominates the standard introductions to the subject [...]. Certain features of Muslim juristic discourse, those perhaps which are most revealing of its nature and intentions, are in such works disregarded $[. . .]^{14}$

12 B. Messick, 'Just writing: paradox and political economy in Yemeni legal documents', Cultural Anthropology 4(1) (1989): 26-27.

13 Messick, ibid., p. 35 .

14 N. Calder, 'Law', in O. Leaman \& S. H. Nasr (eds.), History of Islamic Philosophy (London and New York: Routledge, 1996) 979 . 
Significantly for the topic of this article, Calder refers to the book by Nabil Saleh on Islamic finance principles to exemplify the attempt of 'reasserting Shari'ah as a valid and sensible corpus of commercial and civil laws ${ }^{15}$ in contemporary times.

What he wants to achieve is a "financial system based on Islamic ethics" [...]. What stands in his way... is the tradition of Muslim juristic writing. He goes through it honourably; but its variation, its complexity, its extravagant exploration of detail, its constant citation of different authorities, its apparent irrelevance, sometimes, to practice, its cunning and witty accommodation, sometimes, to practice: all these things make his task difficult, and will alert his readers to the fact that "a valid and sensible corpus of laws" is not quite what these jurists had in mind..$^{16}$

So, what else had fiqh jurists in mind? Any sensitive reply to this question requires, I believe, to broaden our investigation to classical Islamic theology as background for figh conception of justice. In orthodox Aš'arī theology, justice ('adl) equals the revealed 'Path' (Šarī'ah) establishing what is 'right', 'true', 'real' (haqq) according to God's Will. It is within this Qur'ānic paradigm that the reality is conceived as direct manifestation of God's sovereignty. ${ }^{17}$ 'To... [God] is due the primal origin of the heavens and earth. When He decreeth a matter, He saith only "Be", and it is (kun fa-yakün)' (Q. 2:117): God's perpetual creative power is the leitmotiv throughout the entire Qur'ān since 'everything that occurs, does occur necessarily, but not because in and of itself it must. It occurs necessarily because of God's prior decree and volition'. ${ }^{18}$ It is God's decree (ḥukm, pl. aḥkām) to 'judge', 'order', 'rule' the reality by defining the moral status of human actions: and correspondingly personal rights (ḥuquqq, pl. of haqqq) ${ }^{19}$ are the means through which God realises (in the proper sense of 'making real') His decrees within

a vision of reality as being in its essence imperative, a structure not of objects but of wills. The moral and ontological change places, at least from our point of view. It is the moral... which is a thing of descriptions, the ontological... which is one of demands. [...] The "real" here is a deeply moralized, active, demanding real, not a neutral, metaphysical "being"...; a real of prophets not philosophers. ${ }^{20}$

This deep interrelation between the 'real' and the 'legal' ('in Islamic legal sensibility, to determine the empirical situation is to determine the jural principle. Facts, in other words, are normative, there is no fact/law dichotomy') $)^{21}$ is confirmed by the etymology of 'right' (haqq), with the Arabic root $H-Q-Q$ meaning at the same time to be 'real', 'true', 'legal', 'right', 'correct'. If 'the primary meaning of haqq is "established fact" or "reality" (al mawjūd al thābit), in the field of law its dominant meaning is "truth" or

15 N. Saleh, Unlawful Gain and Legitimate Profit in Islamic Law. Riba, Gharar and Islamic Banking, Cambridge Studies in Islamic Civilisation (Cambridge: Cambridge University Press, 1986), 4.

16 Calder, supra note 14 at 979.

${ }_{17}$ I. R. Netton, Allah Transcendent: Studies in the Structure and Semiotics of Islamic Philosophy, Theology and Cosmology (London: Routledge, 1989), 22.

18 E. L. Ormsby, Theodicy in Islamic Thought. The Dispute over al-Ghazali's "Best of All Possible Worlds" (Princeton: Princeton University Press, 1984), 195-196.

19 See the entries hukm and haqq in H. Wehr, A Dictionary of Modern Written Arabic (ed. By J.M. Cowan; IV ed.) (Wiesbaden: Harrassowitz, 1994).

20 C. Geertz, 'Local knowledge: fact and law in comparative perspective', in C. Geertz (ed.), Local Knowledge. Further Essays in Interpretive Anthropology (New York: Basic Books, 1983), 187-188.

${ }^{21} \quad$ S. E. Merry, 'Legal pluralism', Law and Society Review 22(5) (1988): 886. 
"that which corresponds to facts." Both meanings are equally prominent'; ' $[\mathrm{t}]$ he primitive sense of haqqq is 'established fact' (al-thäbit haqiqat $\left.{ }^{a n}\right)[\ldots]$ [a]nother meaning of haqqq... is 'demand' or 'right', as legal obligation'. ${ }^{23}$

Why then 'a valid and sensible corpus of laws' cannot depict Šarīah as understood in classical fiqh? This depends on the fact that Muslim juristic discourse, by endorsing God's supremacy in man's agency (with the personal right, haqq, realising God's decree, hukm), proceeds by deeming each individual and circumstance as unique and the effort ( $i g ̆ t i h \bar{a} d)$ of understanding Šarīah necessarily occurrencespecific. Accordingly, as noted by Wael Hallaq,

there was no point in stating the law in the way that it is recorded in today's legal codes. Rather, the law was an ijtihadic process, a continuously renewed exercise of interpretation. It was an effort at mustering principles as located in specific life-situations... Islamic law was not fully revealed unto society until the principles meshed with social reality and until the interaction of countless social, moral, material and other types of human relations involved in a particular case was made to come full circle. ${ }^{24}$

Looking at this ijtihadic process in medieval trade from the perspective of entextualisation, one can note how actions in figh legal texts (by linking Šari`ah to the world of commercial practice) were judged by rules that were legitimised by their own local context. In other terms, fiqh was a process of locating Šari’ah in context, and its social anthropology worked in a 'calligraphic', 'handwritten' way by inserting the meaning of legal opinions in a textual polity grounded on specific life-situations. In this regard, the essential features of figh legal texts can be listed as follows, with some paradigmatic examples:

a. real-life approach to Islamic law in relation to human actions. Fiqh literature consisted of cases aimed at solving real-life problems, as in this discussion from the Kitāb al-Mahâriğ fi al-Hiyal by the great Ḥanafi jurist al-Šaybānī (749/50-805).

I said: 'What is your opinion of two men wishing to form a partnership with their possessions, one of whom has merchandise worth five thousand dirhams and the other merchandise worth one thousand dirhams?' He said: 'Partnership in goods is not permissible'. I said: 'What type of... [stratagem] can they employ which would make partners in the merchandise they possess?' He said: 'Let the owner of the merchandise worth five thousand dirhams purchase five-sixths of his colleague's merchandise with onesixth of his own. If they do this, they will be partners in accordance with their shares in the investment.' ${ }^{25}$

${ }^{22}$ M. H. Kamali, 'Fundamental rights of the individual: an analysis of haqq (right) in Islamic law', The American Journal of Islamic Social Sciences 10(3) (1993): 342.

${ }_{23}$ D. B. MacDonald \& E. E. Calverley, ' Haqq', in P. J. Bearman, T. Bianquis, C. E. Bosworth, E. van Donzel \& W. P. Heinrichs (eds.)' Encyclopaedia of Islam, Second Edition, online at https://referenceworks.brillonline.com/browse/encyclopaedia-of-islam-2, accessed 5 September 2018.

${ }_{24}$ W. B. Hallaq, An Introduction to Islamic Law (Cambridge: Cambridge University Press, 2009), 166-167; italics in the original text.

${ }^{25}$ Quoted by A. L. Udovitch, Partnership and Profit in Medieval Islam (Princeton: Princeton University Press, 1970 ), 63. 
b. as a corollary, a strong particularistic casuistry characterized fiqh: a quality that was 'part of the doctrine, not an exterior element that explains it'. ${ }^{26}$ So figh legal texts

often read like an odd supermarket catalogue that mentions Transoxanian yoghurt, tigerbones, elephant-teeth, dogs, birds and glass, grain, flour and mash, slaves and wine, musical instruments, chessboards and figures, fruits and juices, snakes and scorpions, houses and dresses, and different sorts of meat. ${ }^{27}$

c. pluralistic solutions in context, the best one to be chosen among different alternatives. A good example with regard to the payment of zakāt can be found in the Muhadd $\underline{a} b$ by the Šăfi'i jurist al-Shīrāzī (1003-1083).

Chapter on the distribution of alms $[\ldots]$

2:0 On the question which is the best mode of conduct, there are three views.

2:1 $\quad[\ldots]$ the owner of wealth should distribute his zakāt by himself. [...]

2:2 [...] he should pay the Imām, whether the Imām is just or unjust. This is because of what is related concerning Mughīrah ibn Sha'bah.... Another reason: the Imām is more knowledgeable about the poor and the extent of their need.

2:3 [...] if the Imām is just, payment to him is the best mode of conduct, but if he unjust, then distribution by the owner of the wealth is best. This is because of the Prophet's words, He who asks for it as it should be, let him be given it; he who demands more than he should, let him not be given it. Further, the donor is secure in paying it to a just Imām, but is not secure in paying it to an unjust Imām, for the latter may spend it on his own desires. $^{28}$

In the next section we will investigate which change of textual polity has occurred in the transmission of Šarīah value from medieval trade to Islamic finance, and which impact the process of Shariahcompliance holds for the contemporary meaning of Islamic law.

\section{$3 \quad$ Shari'ah-Compliance and the Textual Polity of Islamic Finance}

With reference to the social anthropology of medieval trade $\S 2$ has underlined how fiqh legal texts located Šarīah in context (so to 'materialise' its Text in commercial practice): the process of entextualisation worked in a 'handwritten', 'calligraphic' way and the social value of juristic solutions was grounded on rules that were legitimised by real-life situations. Moving now to contemporary times, how much 'material entextualisation' in Islamic contracts and securities arises from the process of Shari'ah-compliance? Is the Šarīah value of Islamic finance the same of fiqh rules, or has the passing of time radically transformed 'Islamic law'?

While the legitimacy of Islamic financial transactions is certainly grounded on (better, backed by) Šarī'ah, it seems to me that today's Shari'ah-compliance departs from the 'real', 'right' (haqq) of social

${ }_{26}$ B. Johansen, 'Casuistry: between legal concept and social praxis', Islamic Law and Society 2(2) (1995): 156.

${ }^{27}$ Johansen, ibid., p. 147.

28 Quoted by Calder, supra note 14 at 991-992. As Calder notes, each paragraph (2.1, 2.2 and 2.3) is constituted by a rule and a justificatory argument, but the ihtilâf (i.e. the existence of diverse legitimate solutions) is unresolved, since none of the three reasons for concern unequivocally overrides the others. 
relations towards a 'de-materialised Šarīah' where the meaning of Islamic law is embodied in the validation of contracts and sukuk (see note 8 ) rather than human actions. ${ }^{29}$ In this precise sense, if in classical fiqh actions were judged by rules legitimized by their own context, in the process of Shariahcompliance the Islamic legitimacy of financial products is ratified through certifications owning a legitimacy that is formulated context-less. As a result, the Shari'ah-compliance process entextualised in Islamic contracts and sukuk has replaced Šarīah as Text inscribed in the reality: and correspondingly, in this new textual polity, the meaning of Islamic law relates more to standardised products and securities $^{30}$ rather than actual social interactions. One should also note that this shift reflects a much wider turn towards a rationalistic and purposive epistemology of Islamic law (through the maqāșid alŠari'ah, 'the objectives of Shari'ah'), ${ }^{31}$ of which the process of Shari'ah-compliance is clear manifestation: not by chance the reference to maqāssid is widespread in Islamic finance, defining the meaning of Islamic law for individual action more in terms of efficiency than morality (see Conclusions, § 4).

A move towards a de-materialised Šarīah has occurred in the social anthropology of Islamic finance within a textual polity whose paradigm 'text' is not anymore the Text (the Qur'ān) but has split into standardised legal texts (the certifications by Shari'ah scholars embodying Shari'ah standards) and the contractual texts of Islamic transactions and sukuk. So, in a context where financial standardisation acts per se as a law-making process (see note 29),

- $\quad$ if the authority of legal texts is backed by the Qur'àn, the Text par excellence in Islam,

- their transmission is deprived of any (local) context,

- their interpretation is more procedural than substantially linked to the real economy,

- and their inscription has little to do with social reality, with a meaning of Islamic law that stands for the validation of standardised transactions and securities rather than of singular human actions: in summary, for a de-materialised Šarīah that, being detached from any context, mirrors itself the financial nature of our contemporary global market.

In this way, Shari'ah-compliance texts have inserted an additional layer of authority transmission in the space of Islamic finance: a layer that is certainly functional to the processes of standardisation and securitisation, but where the time of 'Islamic law' belongs more to global finance and its legal/financial technology rather than to Islamic religion and morality. In this four-layered interaction

$\operatorname{Text}($ Šarīah $)$

legal texts (Shari'ah-compliance certificates)

texts (contracts under judgement, so to validate financial operations and securities)

(socio-economic) world

${ }_{29}$ In a recent article Jonathan Ercanbrack describes the process of standardisation of Islamic financial law in terms of a 'lawmaking effort that is incentivized by market forces and the interaction of municipal legal systems' (J. Ercanbrack, 'The standardisation of Islamic financial law: lawmaking in modern financial markets', The American Journal of Comparative Law, https://doi.org/10.1093/ajcl/avzo10, accessed 3 March 2020). Ercanbrack examines the impact of standard-setting bodies (such as the AAOIFI, the Accounting and Auditing Organization for Islamic Financial Institutions) in developing 'private Islamic legal standards' through a standardisation effort that, in his view, 'must be realized if authentic sharia principles are to be given effect' (italics added). To the extent to which I subscribe Ercanbrack's analysis about the impact of standardisation in Islamic finance law, I suspect that this authenticity of Shariah in the global market does not precisely correspond to that of Šarīah in fiqh medieval trade (see Conclusions).

$3^{3}$ Products standardisation clearly appears from the classic definition of investment sukuk by AAOIFI as 'certificates of equal value representing undivided shares in ownership of tangible assets, usufruct and services or (in the ownership of) the assets of particular projects or special investment activity': AAOIFI Standards for Islamic Financial Institutions (Manama: AAOIFI, 2015), Shari'ah Standard n. 17, p. 468, paragraph 2.

$3^{11}$ D. Johnston, 'A turn in the epistemology and hermeneutics of twentieth century ușūl al-figh', Islamic Law and Society $11(2)(2004): 233-282$. 
legal texts evaluate contractual texts within a textual polity that is constituted by standardised certificates, products and sukuk and not anymore by human beings. Here, the world of social action is not judged according to Šarīah anymore: on the contrary, contracts and securities are judged by Shari'ah-compliance certificates in the financial world. It is precisely in this way that the social anthropology of Islamic law has experienced in-time a tremendous transformation in the form of a dematerialised Šarīah.

But what does this transformation imply?

It's difficult at this point to keep from commenting.

This picture ['Islamic law', our Hiroshige's print] is by no means innocent.

Time has been stopped here.

Its laws are no longer consulted.

It has been relieved of its influence over the course of events.

It has been ignored and insulted..$^{2}$

Indeed, while in global Islamic finance the authority of 'Islamic law' is backed by the Text of Šarīah, (more importantly) it is embedded in Shari'ah-compliance texts, as both sociological and economic researches have shown. For instance, a publication by Funds@Work ${ }^{33}$ has highlighted how the 'small world of Islamic finance' gathers a limited number of Shari'ah scholars whose signatures provide valuable (since 'authoritative') certifications. Correspondingly, these signatures render valuable ('economically profitable') Islamic securities: 'the choice of scholars hired to certify these securities matter for the market valuation of the issuing company'. ${ }^{34}$ In summary, within the space of Islamic finance the world where the meaning of Islamic law is inscribed has become the financial world, a 'world of texts', contracts and sukuk, not of real people; financial products have replaced actual social actions; Shari'ah-compliance have replaced Šarī'ah; technology has replaced the Text (see also later, § 4). The shift from a textual polity connecting the Text to the world to a textual polity connecting legal texts to contracts and securities can be seen in this Shariah Approvalfor Meezan Kafalah.

Meezan Kafalah is a Shariah-compliant alternative to Banc assurance that offers a unique combination of saving, investment and protection. [...] Meezan Kafalah is a recurring deposit plan... The Bank will offer profit on deposited amount while the Takaful partner will provide Takaful cover. The underlying contracts of Meezan Kafalah are Mudarabah and Wakalah. In Mudarabah, funds deposited by the customer are allocated to a deposit pool, which are invested in Islamic modes of finance. [...] In Wakalah, the customer will agree to appoint Meezan Bank as his/her Wakeel (agent) for facilitation obtaining the Takaful cover. [...]

"... Resolved that the modus operandi defined above for the Meezan Kafalah is according to the dictates of Shariah.... ${ }^{35}$

${ }^{32}$ Szymborska, supra note 6, pp. 167-168.

33 Funds@Work, "The Small World of Islamic Finance. Shariah Scholars and Governance - A Network Analytic Perspective' (2010), available online at: https://funds-at.work/wp-content/uploads/2018/o2/Sharia-Network-by-Fundsat-Work-AG.pdf, accessed 25 May 2018.

34 C. J. Godlewski, R. Turk and L. Weill, 'Do the type of sukuk and the choice of Shari'ah scholar matter?', IMF Working Paper WP/14/147 (2014).

35 M. I. Usmani, 'Shariah Approval for Meezan Kafalah' (2014), available online at: https://search.emarefa.net/ detail/BIM-727547?index=14, accessed 6 March 2019. The simplified transliteration of Arabic terms follows the change in meaning from 'Šarī'ah' to 'Shari'ah' (see note 8). 
The three qualities of figh textual polity $(\S 2)$ have disappeared in this Shari'ah certificate in

a. a text-based approach to Islamic law in relation to contractual forms, not human actions;

b. the standardisation of context-less operations;

c. uniform outputs that are functional to the efficiency of transactions management in the governance of Islamic financial institutions.

Correspondingly, the (religious) Truth of $\breve{S} a r^{\top} a h$ has been substituted in Islamic finance law by the (procedural) truth of (Shari'ah-)compliance, with a predominance of elements of legal and financial technology as epistemological environment for its assertion (see $\S 4$ ).

In fact, 'compliance' - from the Italian complire, 'to complete', 'fulfil', 'accomplish' - has no religious meaning and there is no 'Islamic law' definition of compliance. Instead, the notion belongs to the field of organisation technology: Governance, Risk Management and Compliance (GRC) is today a subfield of business administration with GRC defined as 'the integrated collection of capabilities that enable an organization to reliably achieve objectives, address uncertainty and act with integrity'. ${ }^{36}$ Hence, one can think of legal compliance as a tool of governance which aims to review, verify and certify that the organization's procedures and outcomes comply with the law in the broader sense (international, national, local legislation, codes, standards and so on); accordingly, Shari'ah-compliance has become today part of the technology of (Islamic) financial institutions, with a meaning that belongs more to the realm of governance rather than of (Islamic) law/religion.

Shari'ah-compliance reflects a governance technology where the value of transactions, contracts and securities relates to standardisation: and in this frame the $\breve{S}$ ari $a h$-value of $f i q h$ 'calligraphy' has been replaced by a de-materialised Shari'ah which is 'typewritten' in market-values.

In brief, Islamic finance has given rise to a Typewritten Market as socio-anthropological space for contemporary Islamic law.

Conclusions. The Typewritten Market: Islamic Law in the Time of Legal/Financial Technology

In one of his books Italian philosopher and psychoanalyst Umberto Galimberti notes how today

technology has become the environment... that constitutes ourselves in accordance with... [its own] rules of rationality..., functionality and efficiency [...]. But technology does not tend to an aim, does not promote a sense, does not open scenarios of salvation, does not redeem, does not unveil the truth: technology [simply] functions. ${ }^{37}$

Even the perception of contemporary truths (if not the Truth) is affected by the rationales of technology - and the functionality of maqāsid purposive approach may be indirect proof of this claim. ${ }^{3}$ What can we add to all this? Certainly, if Hiroshige's 'little picture' is 'by no means innocent', neither is the meaning of 'Islamic law' in Islamic finance.

${ }^{36}$ S. Mitchell, 'GRC36o: A framework to help organisations drive principled performance', International Journal of Disclosure and Governance 4(4) (2007): 279-296.

37 Synopsis of U. Galimberti, Psiche e Techne. L'Uomo nell'Età della Tecnica (Milano: Feltrinelli, 1999); my translation.

$3^{8}$ Johnston, supra note 31. 
For generations, it's been considered good form here

to think highly of this picture [Islamic law],

to be entranced and moved.

There are those for whom even this is not enough.

They go so far as to hear the rain's spatter [Islamic law's conceptual power],

to feel the cold drops on their necks and backs,

they look at the bridge and the people on it

as if they saw themselves there,

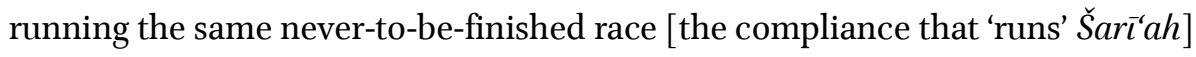

through the same endless, ever-to-be-covered distance [the efficiency of technology],

and they have the nerve to believe

that this is really so [that Shari'ah-compliance equals Šaríah]. ${ }^{39}$

If at the beginning of this article $(\S 1)$ we imagined being under the rain, at the end of Hiroshige's Bridge the race by Islamic finance People can illuminate, I believe, their meaning of 'Islamic law'.

As much Szymborska's People keep running on the Bridge, so Islamic finance actors keep asserting 'Islamic law' despite the lack of its consistent application in global finance: in the end, it is the representative power of the concept (the 'rain's spatter' that they feel) that counts to depict the alternative identity of Islamic finance in comparison with the conventional market. But, being their present (presence in-time) immersed in a social reality dominated by an 'ever-to-be-covered distance', their only option is a 'never-to-be-finished race': as 'technology [simply] functions', so Shari'ahcompliance locate their actions in a 'race' that 'runs' (in the sense of 'operates') Šarī'ah. In a nutshell, the 'Path' is not 'followed' anymore (as it was in fiqh); rather it is 'put at work'.

Although someone may have 'the nerve to believe' that Shari'ah-compliance equals Šarīah, this article warns the reader about the radical transformation that the former embeds for the social anthropology of Islamic law. While standardisation works as a law-making process where Islamic law is functional to Islamic finance operations (note 29), many Muslim believers, 'subject to [the] time [of financial/legal technology], ... won't admit it'. Rather, they would prefer 'a way of expressing protest': precisely, Shari'ah-compliance as simulacrum of Islamic law. But, if Shari'ah-compliance belongs to the world of technology, so the reference to 'Islamic law' becomes a 'dialectical signature' for the market: a sign of community belonging to Islam in a world of legal/financial technology to which (of which?) Muslim believers (as everybody else) are subject(s). Reduced to a procedural step in the governance of Islamic financial institutions, Šarīah (Shari'ah?) substantially 'works' in compliance with the standards that 'run' the market. ${ }^{40}$

As a result, the 'calligraphic' trade of fiqh has been replaced by 'typewritten' certificates, contracts and securities, giving rise to a textual polity detached from actual social relations: in summary, to a Typewritten Market that embodies a de-materialised Šarı̌ah, where the meaning of Islamic law in-time belongs more to legal/financial technology rather than to Muslim human action.

This article has underlined above how this semantic transformation can be related to the purposiveoriented epistemology of ușül al-figh. Other interpretive suggestions have been advanced by legal

39 Szymborska, supra note 6, pp. 168-169.

$4^{\circ}$ As explained in note 8, even the simplified transliterations 'Shari'ah-compliance' and 'sukuk' can be seen as a vehicle of meaning for the standardisation of Islamic law (see also Ercanbrack, supra note 29). 
anthropologists with regard to the impact of Western legal culture on Muslim countries: ${ }^{41}$ in Islamic finance, I think, this impact has undertaken a step forward by transplanting the technologies of standardisation and securitisation in the mechanism of Shari'ah-compliance.

I would like to close our voyage over the Bridge referring to the review of Messick's book by Houari Touati, French cultural anthropologist and historian. We have previously noted how much the signature by Islamic scholars affects the valuation of Shari'ah-compliant securities. ${ }^{42}$ Quoting a volume by Béatrice Fraenkel, ${ }^{43}$ Toauti sheds light on the transformation of the meaning of texts in the Western society through 'the appearance of the signature... as a sign of recognition of the singularity of the being. ${ }^{44}$ This singularity has emerged in connection to the modern state (the polity that guarantees the signature as the 'sign' of personal identification) and has been reinforced in the 'era of the triumphant colonial capitalism' - something that Hannah Arendt and Pierre Legendre have described as the 'romanisation of the world'. ${ }^{45}$ If on the one side we can draw some revealing connections between this process and the 'latinisation' of Islamic finance alphabet (see both notes 8 and 29$),{ }^{46}$ on the other side Touati interprets 'the development of political Islamism, convoking... the return in force of religion dislodged from the management of the affairs of the city, as a reaction to the romanisation of the Muslim world'. ${ }^{47}$

On this specific point, there is no doubt that Islamic finance, differently from political Islamism, witnesses a re-emergence of Islam that is lodged (not 'dislodged') in 'the management of the affairs of the city'. But to which extent is the signature of financial products by Shari'ah scholars a 'return in force of religion' rather than a manifestation of the singularity that belongs to the 'era of the triumphant colonial capitalism'? Isn't this signature ('a sign of recognition of the singularity of the being') further manifestation of the 'dialectical signature' of Shari'ah-compliance, acting as simulacrum of Islamic law?

Looking at Islamic finance People running over the Bridge, as we have done in these pages, can provide, I think, good interpretive clues to give a reply to these topical questions too.

${ }^{41} \quad$ L. Buskens \& B. Dupret, "The invention of Islamic law: a history of Western studies of Islamic normativity and their spread in the Orient', in F. Pouillon \& J.-C. Vatin (eds.), After Orientalism. Critical Perspectives on Western Agency and Eastern Re-Appropriations (Leiden \& Boston: Brill, 2015): 31-47.

42 Godlewski, Turk \& Weill, supra note 34.

43 B. Fraenkel, La Signature. Genèse d'un Signe (Paris: Gallimard, 1992).

44 H. Touati, 'Review of The Calligraphic State. Textual Domination and History in a Muslim Society by B. Messick', Annales. Histoire, Sciences Sociales 49(4) (1994): 998, my translation.

45 As reported by Touati, ibid., p. 999.

${ }^{46}$ In metaphorical terms, a 'transliteration' of Islamic finance into the semantic forms of Western modern law has occurred, with a predominance of a business/legal language in Latin alphabet (that of 'Shari'ah-compliance' and 'sukuk') instead of the moral/religious language of Šarīah (originally formulated in Arabic in classical fiqh).

47 Touati, supra note 44, p. 999. 